International Journal of Instruction e-ISSN: 1308-1470 • www.e-iji.net

Article submission code: 20200123124611

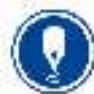

January $2021 \bullet$ Vol.14, No.1

p-ISSN: 1694-609X

pp. 507-520

Received: 23/01/2020

Revision: 07/07/2020
Accepted: 29/07/2020

OnlineFirst:25/10/2020

\title{
Causative Correlation of Teacher's Motivation and Discipline in Banyumanik, Semarang City
}

\section{Muhamad Afandi}

Doktoral Student., Universitas Negeri Jakarta, Jakarta, Indonesia, and Lecturer, Universitas Islam Sultan Agung-Semarang, Indonesia, mafandi@ unissula.ac.id

\section{Zulela MS}

Prof., Universitas Negeri Jakarta, Jakarta, Indonesia, zulelams@unj.ac.id

\section{Amos Neolaka}

Prof., Universitas Negeri Jakarta, Jakarta, Indonesia, aneolaka@ unj.ac.id

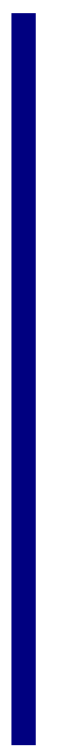

The interaction between elementary school teacher's motivation and discipline in Indonesia has not been mapped well. This study aimed to identify patterns of motivation and discipline relationships using causality structural approaches to obtain more comprehensive understanding. This study was used an observational and quantitative descriptive method. A total of 162 elementary school teachers in Semarang City were involved as respondents, randomly. Teacher motivation and discipline were observed then analyzed using structural equation modelling (SEM) performed by LISREL software packages and SPSS. Teacher assessment results were grouped base on gender and work experience. The discipline was significantly positively correlated with motivation. The pattern of relationships between latent variables (motivation and discipline) showed a significant amount of good lead correlation. The value of $\mathrm{R}^{2}$ between them reaches 0.80 indicating that the two variables affect each other higher enough. Furthermore, findings related to teacher motivation and discipline does not have differences between groups and gender, that means motivation and discipline both in gender and all work experiences were as equal as high performance. This research found that motivation is a strong driving factor to make teacher more discipline. The discipline itself pop up by high achievement or appreciation. The discipline also makes teachers get more positive achievement that may motivating them

Keywords: causative correlation, discipline, motivation, structural equation modeling, elementary teacher

\section{INTRODUCTION}

Indonesia's national education aims to develop students' potential in terms of spiritual, emotional, and intellectual quotient. The realization of these ideals is internalized in 
educational institutions both in the public and private schools where the teacher is a leader of the process. To support the process, it is appropriate for a teacher to have academic qualifications, creative learning and self-competence to support his role as a facilitator and a mentor (Goodyear \& Dudley, 2015; Rotgans \& Schmidt, 2011). These qualifications are needed to create student-centered learning process, thereby increasing the meaningfulness of learning process (McCabe \& O'Connor, 2014; Thomas, 2010)

In the process, the teacher is seen as a role model who can inspire their students. Therefore teachers should have certain good personal quality standards that include responsibility, authority, independence and discipline (Esa, 2010; Ulug, Ozden, \& Eryilmaz, 2011). The teacher's disciplinary attitude is manifested through adherence to the rules and principles of professionalism, because it is tasked with disciplining students, especially in the class (Margutti, 2011).

High level of work discipline, likely influenced by high level of work motivation, and vice versa. High motivation may also arise due to high discipline (Han \& Yin, 2016). Both the attitude of discipline and motivation, will increase the willingness and capacity of teacher's quality to complete the task, quickly and precisely (Gutiérrez, Ruiz, \& López, 2010; Moreno-Murcia, Sicilia, Cervelló, Huéscar, \& Dumitru, 2011). Motivation can be translated into many forms. However, there are little researches have explored to understand how the relationship between discipline and motivation in elementary teachers. Higher authority performs some motivational programs to increase elementary teacher discipline, but, the result itself is not clearly counter what the problem is. Hence, this study aimed to identify patterns of discipline and motivation relationships in the teacher, using structural equation modeling approaches to obtain a more comprehensive understanding to increase teacher's performance.

\section{METHOD}

This study used an observational and quantitative descriptive method to elaborate correlation between elementary school teachers' motivation and discipline. The respondents were elementary teachers in Banyumanik Sub-district, Semarang City, Indonesia. The main construct were discipline and motivation that calculated using structural equation modelling (SEM). The sampling technique was carried out using stratified random sampling, and respondent was determined randomly using lottery. A total of 272 elementary school teachers was included in this research from seven branches of Subject Teacher Group Discussion (MGMP) in Banyumanik Sub-district. Then, 162 teachers for respondents was randomly selected using Slovin's formula with confident interval $95 \%$ and margin of errors was $5 \%$. Gender composition of the sample size was consisted of 28 male and 134 female teachers.

Teacher performance data were observed using observational instruments equipped with rubric ratings from 1 to 4 . The observer in this study was the principal from same school as the respondent work home-base. Before the instrument used to collect data, observers were trained with data collection techniques and observations to avoid differences in perspectives bias. The instrument used for data collection was validated by three elementary school learning experts. Expert validation aimed to determine the 
shortcomings of instruments. The gender and work period was used as determiner to explore the correlation of both determiner to the motivation and discipline indicators.

\section{Instrument Calibration}

The validated instruments by experts were used for data collection of teacher's motivation and discipline performances. Validity test was done through calculation of Product Moment and Pearson correlation coefficients. The questionnaires stated as valid instrument if it fulfilled the criteria for $\beta$-value $<0.05$, at $\alpha=5 \%$, based on that, the questionnaires that does not fit the criteria is stated as invalid. The results of the instrument validation was indicated that all instruments have $\beta$-value $<0.05$, or in other words that all statements in the teacher's performance observation sheet were valid and reliable to collect the data

\section{Data analysis technique}

Structural equation modeling (SEM) analysis was carried out using software packages LISREL version 8.80 (Vieira, 2011). Relationship between variables and indicators was estimated based on maximum likelihood (ML) algorithm with input for each analysis was covariance matrix of items or scale scores (Voelkle et al., 2012). The main variables were teacher's motivation and discipline that expressed as hybrid construct, which were analyzed by a causative relationship of five indicators for motivation and four indicator for discipline.

Variable as used in this research that is motivation and discipline. Motivation as exogenous latent variable (independent) and discipline as endogen latent variable (dependent). Variables measured by observed parameter for each indicator. Variable motivation consist of 5 indicator that is try to be superior (X1), finish all task (X2), rational for getting to success (X3), accept and be responsible (X4), and receive feedback on the work taking into account risk (X5). Variable discipline consist of 4 indicator that is enter work and adhere to the conditions of working hours (Y1), achieve the specified teacher work goals (Y2), take advantage of the work atmosphere (Y3), and provide service to the society (Y5) (Table 1).

Table 1

Structural component definition to construct SEM path analysis

\begin{tabular}{|c|c|c|}
\hline $\begin{array}{l}\text { Class of } \\
\text { Variable }\end{array}$ & $\begin{array}{l}\text { Latent } \\
\text { Variable }\end{array}$ & Indicator \\
\hline \multirow[t]{5}{*}{ Exogenous } & \multirow{5}{*}{$\begin{array}{l}\text { Motivation } \\
\left(\xi_{1}\right)\end{array}$} & Positive effort to be the best (X1) \\
\hline & & Finishing all tasks on time $(\mathrm{X} 2)$ \\
\hline & & Rational on planning achievements (X3) \\
\hline & & Accepting and responsible the tasks $(\mathrm{X} 4)$ \\
\hline & & Receiving performance feedback by measuring the risk (X5) \\
\hline \multirow[t]{4}{*}{ Endogen } & \multirow{4}{*}{$\begin{array}{l}\text { Discipline } \\
\left(\eta_{1}\right)\end{array}$} & Work assiduous and work hours punctuality (Y1) \\
\hline & & Achieving the determined teacher goals (Y2) \\
\hline & & Creating positive environment for works (Y3) \\
\hline & & Providing services to society (Y4) \\
\hline
\end{tabular}


The results of observations were tabulated and coded, before proceeded to model tested using univariate and multivariate normality. It then, continued with statistically calculation for correlation using Pearson correlation and multivariate regression analysis using Statistical Package for the Social Sciences (SPSS) version 22 for Windows. The assumption of normality was expressed in statistical value of $\mathrm{z}$ (normal data) for skewness (the tendency of data distribution to lean left or right) and kurtosis (the peak condition of the graph is neither convex nor transparent). If the $\mathrm{z}$ value (z-kurtosis and or z-skewness) was greater than $0.05(\alpha=5 \%)$ then it can be said that the data distribution was normal. Calculation and construction of SEM models on data that were not normally distributed $(\mathrm{p}<0,05)$. But, it can be done using the ML-method. Structuring of SEM was constructed by correcting standard errors and some goodness of fit indices (GFI) utilization (Awang, Afthanorhan, \& Asri, 2015; Smits, Timmerman, \& Stegeman, 2016; Tang \& Than, 1999; van Albada \& Robinson, 2007)

The validity hypothesis of the SEM structural model was tested through the Goodnessof-Fit Index (GFI) which consisted of 18 parameters. The SEM's goodness conclusion was determined from how many GFI from 18 parameters is reaching "good fit" result. The SEM result was concluded as a good models when the "good fit" model of the parameter is higher than the good less or marginal fit. In addition, external factors are measured to determine whether there is influence or relevance to teacher performance. The factors measured include gender (male versus female) and the service period of service as a professional teacher.

\section{Model Specification}

This study used an analysis of the structural second order model of confirmatory factor analysis (CFA 2nd order) as a result. It was conducted to see causality correlation between latent variables. Model specifications were constructed by converting path charts into a series of measurement model equations. CFA was performed on more than half of the sample. It was fulfilled the mandatory requirements for structural equation modeling (there is a minimum 100 sample for stable analysis).

\section{FINDINGS AND DISCUSSION}

In this study, correlation between motivation and discipline on elementary school teacher was carried out using nine observed indicators. Motivation was measured based on the teacher's desire to be the best, completing tasks on time, rational in planning achievement, responsible for carrying out the task as an educator and receiving his work's feedback from class, environment, or colleagues. Whereas the latent variable of discipline was measured through work assiduous and work hour's punctuality, achieving the determined teacher's goals, creating positive environment for works and provide services to the community. Each indicator was measured using different sub-indicators with a total of up to 35 questions to measure motivation and 42 questions to measure discipline indicators.

Motivation assessment result was shown that many respondents have a high motivation and a high level of discipline in obeying school rules both in teaching and learning activities and socialization outside of class. Based on the work experience and gender, 
all teachers have high level of motivation and discipline of their jobs. The average value of observation shows that both based on gender and work experience, the teacher's motivation was high but no significantly different among groups (Figures 1 and 2). In addition, the discipline levels among groups was also significantly positively correlated with motivation ( $\mathrm{p}=0.615)$, but no different among groups (Table 2$)$.

Measurement of correlations trend among indicators in one latent variable group was shown that there was a positive correlation indicating that indicators have positive meaning each other. It was likely that each indicator has large enough positive performance to assess the motivation and discipline in elementary teacher performance, so that it was influenced observers to choose the right score to evaluate teacher performances.

Table 2

Correlations value between indicators and variables

\begin{tabular}{|c|c|c|c|c|c|c|c|}
\hline & & \multicolumn{5}{|c|}{ Variables } & \multirow{2}{*}{$\begin{array}{l}\text { Pearson } \\
\text { correlation }\end{array}$} \\
\hline & & $\mathrm{X} 1$ & $\mathrm{X} 2$ & X3 & X4 & X5 & \\
\hline \multirow[t]{6}{*}{ Motivation } & $\mathrm{X} 1$ & 1.000 & $0.676^{* * *}$ & $0.595^{* *}$ & $0.484^{\text {*** }}$ & $0.437^{* *}$ & \multirow{10}{*}{$\begin{array}{l}\text { sig }>0,00 \\
p=0,615^{* *}\end{array}$} \\
\hline & $\mathrm{X} 2$ & & 1.000 & $0.629^{* * *}$ & $0.653^{* *}$ & $0.469^{* *}$ & \\
\hline & $\mathrm{X} 3$ & & & 1.000 & $0.619^{* *}$ & $0.630^{* *}$ & \\
\hline & $\mathrm{X} 4$ & & & & 1.000 & $0.501^{* *}$ & \\
\hline & X5 & & & & & 1.000 & \\
\hline & & Y1 & Y2 & Y3 & Y4 & & \\
\hline \multirow[t]{4}{*}{ Discipline } & Y1 & 1.000 & $0.596^{* * *}$ & $0.511^{* *}$ & $0.449^{\text {*** }}$ & & \\
\hline & $\mathrm{Y} 2$ & & 1.000 & $0.458^{* *}$ & $0.460^{* *}$ & & \\
\hline & Y3 & & & 1.000 & $0.613^{* *}$ & & \\
\hline & Y4 & & & & 1.000 & & \\
\hline
\end{tabular}

**. Correlation is significant at the 0.01 level (2-tailed).

Based on the work experience, both motivation and discipline of the teacher were shown in same data trend. The work experience groups, whose working for 24.1-32 years has the lowest observed motivation value among other groups. These results were in line with the correlated discipline scores and were the lowest compared to the other groups. The highest motivation is seen from the group of teachers who have a service period of less than 8 years and more than 32 years.

The high value of observation on motivation and discipline was also shown in genderbased-respondent groups. Based on gender, majority of the male-teachers were motivated and have high discipline in carrying out their duties as teachers, although not significantly different from the value of female-teachers. But based on the deepening, the level of motivation value fluctuation was more dynamic which means it tends to change compared to discipline in all groups of work experience or gender. It likely caused by a cultural value in community that man is the family's economic mainstay. 


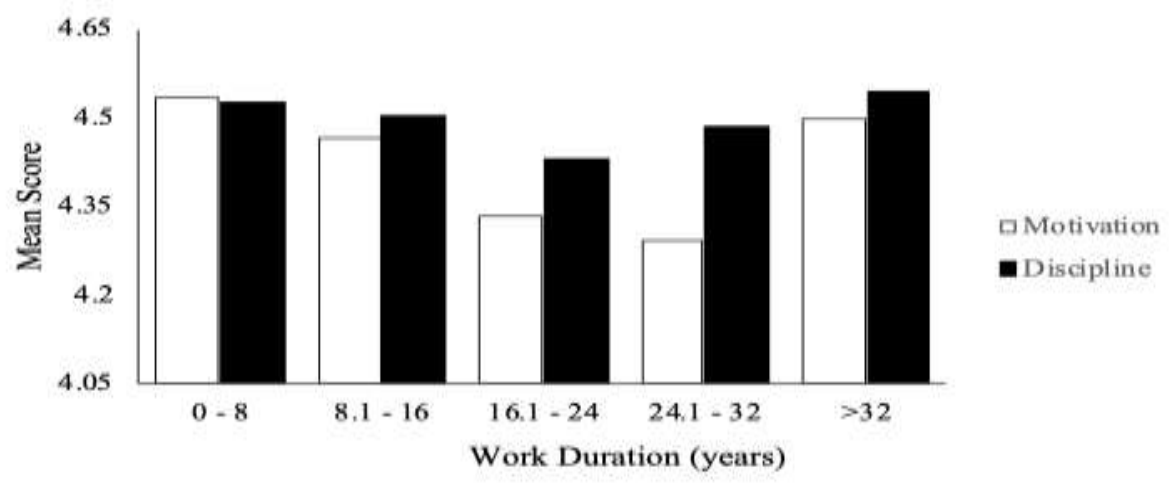

Figure 1

The average value of motivation and discipline of elementary school teachers in Banyumanik by group working period.

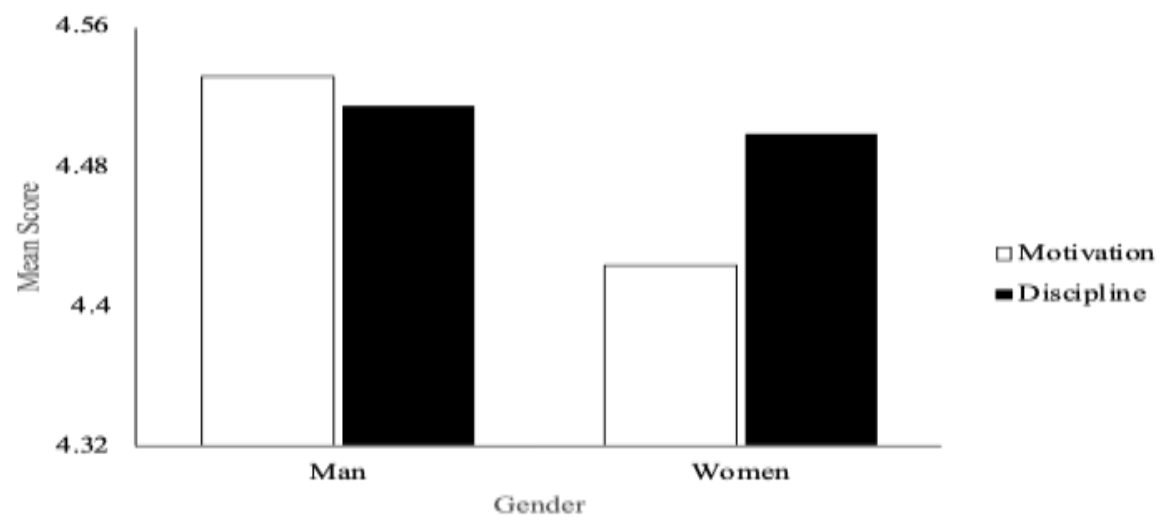

Figure 2

The average score of motivation and discipline of primary school teachers by genders.

\section{SEM Construction}

There were three standard error and goodness of fit indices (GOF) was corrected by LISREL's norm or command. The strategies of errors correction was developed based on the recommendation of LISREL calculation. Errors were fixed by changing loading factor norm become more than 0.05 and correcting negative variant without changing data set. The correction was conducted until each indicator has been valid in constructing work motivation and discipline variables. Even though there were 3 main values in GOF including the chi-square value that is still too large, there was 98.10 ; $\mathrm{p}$ value $=0,000<0.05$ (not significant), and RMSEA value $=0.133<0.05$ (not good). But 13 GOF were stated that SEM calculation was in good fit, and viable to be constructed. 
Modifications were made by allowing covariance errors from Y1 to Y2; X1 with X2; and X3 with X5 to correlate. The advice given was then translated into the command that was entered on the simple worksheet in the LISREL program. The results of the model evaluation was shown that all indicators were valid and feasible to use (Table 3)

Table 3

Evaluation Full Model using multicollinearity

\begin{tabular}{|c|c|c|c|}
\hline Fit Index & Acceptable Level of Compatibility & Index Model & Conclusion \\
\hline Chi-Square & smaller is better & 52.08 & Good Less \\
\hline$P$-Value & $\mathrm{p} \geq 0,05$ & 0,00049 & Good Less \\
\hline $\mathrm{NCP}$ & smaller is better & 29.08 & Good Fit \\
\hline GFI & $\begin{array}{l}\text { GFI } \geq 0,9(\text { good fit }), \\
0,8 \leq \mathrm{GFI}<0,9 \text { (marginal fit })\end{array}$ & 0.93 & Good Fit \\
\hline RMR & $\mathrm{RMR} \leq 0,05$ & 0.0082 & Good Fit \\
\hline RMSEA & $\begin{array}{l}0,05<\text { RMSEA } \leq 0,08 \text { (good fit }), \\
0,08<\text { RMSEA } \leq 1 \text { (marginal fit })\end{array}$ & 0.089 & Marginal Fit \\
\hline ECVI & Closer to saturate ECVI is better & $(0.61 ; 0.57)$ & Good Fit \\
\hline NNFI & $\begin{array}{l}\text { NNFI } \geq 0,9 \text { (good fit }) \\
0,8 \leq N N F I<0,9 \text { (marginal fit })\end{array}$ & 0.97 & Good Fit \\
\hline NFI & $\begin{array}{l}N F I \geq 0,9 \text { (good fit), } \\
0,8 \leq \mathrm{NFI}<0,9(\text { marginal fit })\end{array}$ & 0.96 & Good Fit \\
\hline AGFI & $\begin{array}{l}\text { AGFI } \geq 0,9 \text { (good fit }), \\
0,8 \leq \mathrm{AGFI}<0,9 \text { (marginal fit })\end{array}$ & 0.87 & Marginal Fit \\
\hline RFI & $\begin{array}{l}\mathrm{RFI} \geq 0,9 \quad(\text { good fit }) \\
0,8 \leq \mathrm{RFI}<0,9 \text { (marginal fit })\end{array}$ & 0.94 & Good Fit \\
\hline IFI & $\begin{array}{l}\mathrm{IFI} \geq 0,9 \quad(\text { good fit }) \\
0,8 \leq \mathrm{IFI}<0,9 \text { (marginal fit })\end{array}$ & 0.98 & Good Fit \\
\hline CFI & $\begin{array}{l}\mathrm{CFI} \geq 0,9 \quad(\text { good fit }) \\
0,8 \leq \mathrm{CFI}<0,9 \text { (marginal fit })\end{array}$ & 0.98 & Good Fit \\
\hline PGFI & bigger is better & 0.48 & Good Fit \\
\hline PNFI & bigger is better & 0.62 & Good Fit \\
\hline AIC & Closer to saturated AIC is better & $(96.08 ; 90.00)$ & Good Fit \\
\hline CAIC & Closer to saturated CAIC is better & $(185.60 ; 273.10)$ & Good Less \\
\hline $\mathrm{CN}$ & $\mathrm{CN} \geq 200$ & 134.71 & Good Less \\
\hline
\end{tabular}

Chi-square value decreased from 98.10 to 52.8 , p-value increased from 0.00000 to 0.00049 and RMSEA value decreased from 0.133 to 0.089 . For some other GOF measurements also indicates good fit criteria. From the $18 \mathrm{GOF}$ measurements, 10 parameters showed good fit criteria, 2 parameters showed marginal fit criteria, and 4 parameters showed good less criteria. It can be concluded that the correlation among latent and observed variables of constructed SEM in this research had achieved good fit. From that result, we can assume that the constructed model trusted to measure the correlation between motivation and discipline in the elementary school teacher in Banyumanik sub-district. 
After concluding that the model has a good level of compatibility, the next step is to test the suitability of the measurement model/ CFA (a model that describes the measurement of indicators against latent variables). Validation testing for each indicator were also stated valid and reliable to build SEM construct model.

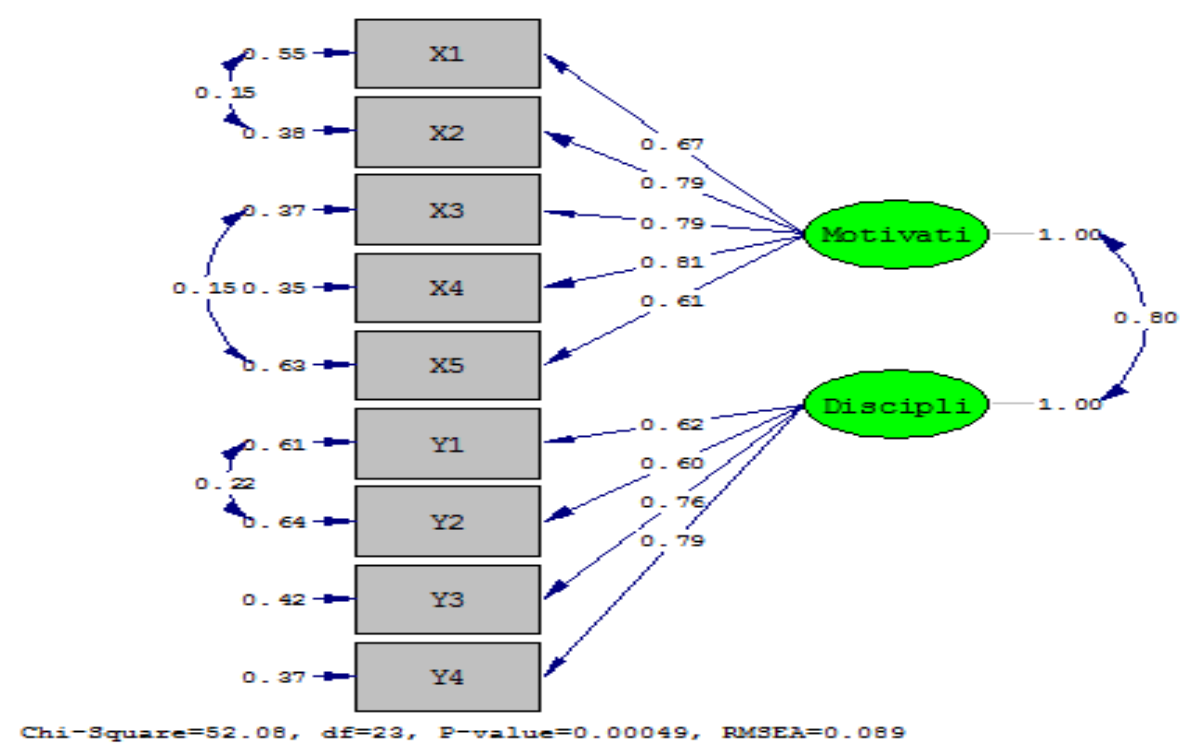

Figure 3

SEM Construct model

The coefficient value of the relationship between motivation and discipline shows a value of 0.80 with a variant error of 0.36 and a value of $R^{2}$ of 0.64 , which illustrates that motivation affects discipline by 0.64 or $64 \%$ while the value of interrelation affects each other worth 0.80 or $80 \%$. Based on the result, it can be indicated that the latent variables (motivation and discipline) indeed influence each other. Increases and decreases in motivation were likely stated to be related to one another.

After correction, overall construct model indicators proposed in the SEM analysis were qualified match to illustrate correlation between latent variables. In addition, the results of the calculation of the observed indicator also indicate a causative relationship that were averages worth more than 0.60 from the latent variable to the observed indicators. It shows that self-motivation and discipline attitude directly contribute and are measured by the observed indicators from the research. The covariant relationship between observed indicators was also shown on the indicators $X_{1} \leftrightarrow X_{2} ; X_{3} \leftrightarrow X_{5}$ and $Y_{1} \leftrightarrow Y_{2}$. 
Table 8

Evaluation measurement model

\begin{tabular}{|c|c|c|c|c|c|c|c|c|c|c|}
\hline $\begin{array}{l}\text { Class of } \\
\text { Variables }\end{array}$ & $\begin{array}{l}\text { Latent } \\
\text { Variables }\end{array}$ & Indicators & Coef & $\begin{array}{l}\text { Error } \\
\text { Var. }\end{array}$ & $\mathrm{R}^{2}$ & $\begin{array}{l}\text { Std. } \\
\text { Loading }\end{array}$ & $\mathrm{CR}$ & VE & Validity & Reliability \\
\hline \multirow[t]{5}{*}{ Exogenous } & $\begin{array}{l}\text { Motivation } \\
\left(\xi_{1}\right)\end{array}$ & $\begin{array}{l}\text { Positive effort } \\
\text { to be the best } \\
\text { (X1) }\end{array}$ & 0.35 & 0.150 & 0.45 & 0.67 & 0.855 & 0.543 & Valid & Reliable \\
\hline & & $\begin{array}{l}\text { Finishing all } \\
\text { tasks on time } \\
(\mathrm{X} 2)\end{array}$ & 0.35 & 0.073 & 0.62 & 0.79 & & & Valid & Reliable \\
\hline & & $\begin{array}{l}\text { Rational on } \\
\text { planning } \\
\text { achievements } \\
\text { (X3) }\end{array}$ & 0.35 & 0.072 & 0.63 & 0.79 & & & Valid & Reliable \\
\hline & & $\begin{array}{l}\text { Accepting and } \\
\text { responsible the } \\
\text { tasks (X4) }\end{array}$ & 0.34 & 0.061 & 0.65 & 0.81 & & & Valid & Reliable \\
\hline & & $\begin{array}{l}\text { Receiving } \\
\text { performance } \\
\text { feedback by } \\
\text { measuring the } \\
\text { risk (X5) }\end{array}$ & 0.26 & 0.110 & 0.37 & 0.61 & & & Valid & Reliable \\
\hline \multirow[t]{4}{*}{ Endogen } & $\begin{array}{l}\text { Discipline } \\
\left(\eta_{1}\right)\end{array}$ & $\begin{array}{l}\text { Self-discipline: } \\
\text { Work assiduous } \\
\text { and work hours } \\
\text { punctuality (Y1) }\end{array}$ & 0.22 & 0.077 & 0.39 & 0.62 & 0.79 & 0.50 & Valid & Reliable \\
\hline & & $\begin{array}{l}\text { Achieving the } \\
\text { determined } \\
\text { teacher goals } \\
\text { (Y2) }\end{array}$ & 0.25 & 0.110 & 0.36 & 0.60 & & & Valid & Reliable \\
\hline & & $\begin{array}{l}\text { Creating } \\
\text { positive } \\
\text { environment for } \\
\text { works (Y3) }\end{array}$ & 0.29 & 0.060 & 0.58 & 0.76 & & & Valid & Reliable \\
\hline & & $\begin{array}{l}\text { Providing } \\
\text { services to } \\
\text { society (Y4) }\end{array}$ & 0.28 & 0.047 & 0.63 & 0.79 & & & Valid & Reliable \\
\hline
\end{tabular}

Note: Coef: data coefficient; R2: Regression coefficient; CR: Construct Reliability; VE: Variant Extracted

Based on the SEM analysis, there was a causal relationship on several indicator items, even though the coefficient value was very low. Causality shown in the observed group of motivational indicators, there were between the teacher's effort to always try to be the best or excellent (X1) and finish work on time (X2) that indicates a special connection. It was shown that the attitude to be the best always complements with hard work to complete all works as a teacher and school's staff, and vice versa. Motivation is also positively related with teacher competent in doing their job, since pedagogical, social, personality, and professional competencies had not been applied well (Arifin, 2015). Completed work on time gives teachers a sense of calm and satisfaction, make them more enthusiastic about teaching (Philipp \& Kunter, 2013). Moreover, it needs selfdiscipline from the teacher to manage their job in the same time. Because, when strong passion to be excellent and hard-working conducted without good self-discipline is impossible to do (Bochner, 1997; Robinson et al., 2016), and easily decrease selfmotivation generally over time (Helms-Lorenz \& Maulana, 2016). 
A causal relationship was also shown between rational attitudes in planning achievements (X3) by receiving feedback on completed work (X5). This result strengthens the fact that teaching assessments and external feedback is importance to improve teacher's planning to achieve their performance goals (Gries-Owen et al., 2018). This research assessment, revealed that teacher conducts performance evaluations as a part of the planning stage to achieve maximum results (Bhatti, Maitlo, Shaikh, Hashmi, \& Shaikh, 2012). One of the ways to improve performance is by receiving critics and advices from school principals, colleagues, students and parents. Teachers' feelings about performance appraisal, and positive collaboration with coworkers encourage them to have high motivation at work (Skaalvik \& Skaalvik, 2011). High motivation encourages teachers to work better and increase their passion to achieve awards or achievements. Contrary to this, low motivation to work reduces expectations and a feeling of self-belonging in completed work so it tends teacher to leave their profession (Skaalvik \& Skaalvik, 2011).

Interestingly, another finding was also stated that expectations for obtaining high rate performance, awards and salary increases through certification, are directly affect teacher's rationality in planning the goals. The allegation that arises as a result of data interpretation is that the increase in welfare is the main reason for respondents in developing self-innovation (Baleghizadeh \& Gordani, 2012). However, the weakness in this study is that no in-depth measurements related to work motivation, work and emotional exhaustion of work, so that no comprehensive understanding of the teacher's real performance is obtained. Therefore, there is a need for scientific and clear justification for assessing the factors that influence teacher performance in the future.

Discipline is an attitude of obedience and compliance with values that are trusted and be a responsibility. In other words, discipline is compliant with regulations or subject to supervision and control. Discipline is an attitude that is always the right promise, practice the rules that have been determined and are responsible. Discipline is very closely related to the trust of others (Osher, Bear, Sprague, \& Doyle, 2010). Selfdiscipline (Y1) is required for teacher to spot themselves in taking neutral action regardless of emotions and moods in the way of their job. In other words, self-discipline is a teacher's self-control and consistency to take certain actions according to the substances, procedures, time limitation, and criteria for achieving teacher's goals in school vision.

The SEM analysis shown that there was a causality relationship between the observed indicators of work assiduous and work hours punctuality with motivation to achieve teacher's goals. Basically, in the daily activities of elementary school in Banyumanik, the teacher is a state warden who is bound by the rules that have been set by its institutions. A sanction(s) for noncompliance with the rules are realized by the teacher. By the motivation and obey the rules, make the teachers has high performed in discipline. The level of caution a teacher has and the accuracy in completing assignments may also be the result of binding regulations (Gregory, Clawson, Davis, \& Gerewitz, 2016). Whereas the teacher's work target is a minimal aspect according to the teacher's work corridor that has been determined by the Ministry of Education and 
Culture which includes pedagogic, professionalism, social and personality aspects, where the standard used is patent. Therefore, teacher performance in the learning process or pedagogical aspects is also interrelated with adherence to regulations because they are regulated in these regulations (Kreber, 2010).

Teacher discipline attitude was also observed by providing services to the community (Y4) indicators. In this case, service to the community at the same time accommodates aspects of personality and social. The teacher acts as a facilitator, mentor and guardian of students in the school who are responsible to parents. Based on this, all aspects involved both in learning and students have an assessment role and can report teacher performance as evaluation material. Nowadays, the student report affectives to improve teachers motivation (Cuevas et al., 2018). and discipline (Raaper, 2019) Based on the results of the assessment shows that most teachers present themselves as obedient individuals and implement office and work regulations. Discipline also shows a positive reciprocal relationship with motivation (Han \& Yin, 2016). The latent variables in this study seem to be highly influential on each other both in each sex and the length of time they served or worked as teachers.

The application of discipline to teachers is an important thing to do to improve teacher performance. In general, the discipline that followed by sanctions increases teacher awareness to do not violate the rules, such as time delays on formulating or achieving goals. Furthermore, discipline in academic performance, tight the teacher up, to support the carrying out of tasks, design work and supervision (Kulga, 2018). Teachers are also required to be able to communicate and interact with peers, students' parents, school principals and the community. Discipline in academic performance is also used to instill positive behavior as student character, self-control, and regulatory compliance at school. Discipline in the work environment is a social control in which power is no longer used to punish individuals who violate, but to increase the potential of students and teachers themselves. In this criterion, teachers are required to be able to create a conducive and orderly work environment. To achieve this, teachers need to create mechanisms that can function as corrective evaluations of various elements of society. By strict discipline, teacher will be helped to build an orderly class and work environment, but it also weaken effectiveness and rise turnover in schools that have a undesirable behavioral climate (Torres, 2016)

This study was shown the strong-relationship between motivation and discipline in elementary school teachers. Even though each variable affected by many aspects, but we found that motivation is a strong driving factor to make teacher more discipline. Then, the discipline attitude makes teachers get more positive achievement that may motivating them. However, this study has several limitations. First, it did not explicitly examine teacher actions in motivating activities or the question did not examine teacher's motivation by their daily activities. This study only asks about job responsibilities and discipline in response to regulations. An important result that can be obtained from this study were the correlation between work compliance levels, motivation and responsibility with the assessment and appreciation of teaching. Another fact shown that majority of the respondents consider about increased salary and 
appreciation (data not shown), they were considered as main triggers in high sense of self belonging on teaching activities and a level of disciplines. Second, even though the construct analysis proves that the used instrument is reliable and valid enough, there are similarities of sub-indicators questionnaires, especially on motivation's observed indicators. Therefore, it is necessary to improve the assessment by adding in-depth interview to find out the main explicit factors that affect motivation and discipline of the teacher.

\section{CONCLUSION}

The pattern of relationships between latent variables, discipline and motivation of elementary school teachers observed showed a significant good correlation. The value of $R^{2}$ between them reaches 0.80 indicating that the two variables affect each other. The relationship between observed indicators also shows the absence of alliance by one aspect. Overall, teachers have a high sense of responsibility, ownership and professionalism so they have the integrity of carrying out the learning process. Furthermore, findings related to teacher motivation and discipline do not have differences in the differences in groups of teaching experience or gender. This research was found that motivation is a strong driving factor to make teacher more discipline. The discipline itself pop up by high achievement from institution (such as, overtime pay) or appreciation from student and community, But discipline attitude also makes teachers get more positive achievement that may motivating them It is needed further observation about elementary school teachers' daily motivation-related-activities and main factors that affect teacher discipline attitude. Furthermore, it needs future research by in-depth interview and teaching observation to measure the work motivation to discipline to emotional exhaustion of work, so that no comprehensive understanding of the teacher's real performance is obtained

\section{ACKNOWLEDGEMENT}

A special thanks is delivered to the Directorate of Research and Community Service, Directorate General of Research and Development, Ministry of Research, Technology and Higher Education of the Republic of Indonesia for providing research grant as a part of the Doctoral research. This original research article was arranged and published as a part of dissertation research to complete the Doctor in Elementary Education at Postgraduate Program of University of Jakarta.

\section{REFERENCE}

Arifin, H. M. (2015). The Influence of Competence, Motivation, and Organisational Culture to High School Teacher Job Satisfaction and Performance. International Education Studies, 8(1), 38-45.

Awang, Z., Afthanorhan, A., \& Asri, M. (2015). Parametric and non-parametric approach in structural equation modeling (SEM): The application of bootstrapping. Modern Applied Science, 9(9), 58. 
Baleghizadeh, S., \& Gordani, Y. (2012). Motivation and quality of work life among secondary school EFL teachers. Australian Journal of Teacher Education (Online), 37(7), 30 .

Bhatti, N., Maitlo, G. M., Shaikh, N., Hashmi, M. A., \& Shaikh, F. M. (2012). The impact of autocratic and democratic leadership style on job satisfaction. International Business Research, 5(2), 192.

Bochner, A. P. (1997). It's about time: Narrative and the divided self. Qualitative Inquiry, 3(4), 418-438.

Cuevas, R., Ntoumanis, N., Fernandez-Bustos, J.G. and Bartholomew, K. (2018). Does teacher evaluation based on student performance predict motivation, well-being, and illbeing?. Journal of School Psychology, 68, pp.154-162..

Esa, N. (2010). Environmental knowledge, attitude and practices of student teachers. International Research in Geographical and Environmental Education, 19(1), 39-50.

Goodyear, V., \& Dudley, D. (2015). "I'ma facilitator of learning!” Understanding what teachers and students do within student-centered physical education models. Quest, 67(3), 274-289.

Gregory, A., Clawson, K., Davis, A., \& Gerewitz, J. (2016). The promise of restorative practices to transform teacher-student relationships and achieve equity in school discipline. Journal of Educational and Psychological Consultation, 26(4), 325-353.

Grise-Owens, E., Miller, J.J., Escobar-Ratliff, L. and George, N. (2018). Teaching note-Teaching self-care and wellness as a professional practice skill: A curricular case example. Journal of Social Work Education, 54(1), pp.180-186.

Gutiérrez, M., Ruiz, L.-M., \& López, E. (2010). Perceptions of motivational climate and teachers' strategies to sustain discipline as predictors of intrinsic motivation in physical education. The Spanish Journal of Psychology, 13(2), 597-608.

Han, J., \& Yin, H. (2016). Teacher motivation: Definition, research development and implications for teachers. Cogent Education, 3(1), 1217819.

Helms-Lorenz, M., \& Maulana, R. (2016). Influencing the psychological well-being of beginning teachers across three years of teaching: Self-efficacy, stress causes, job tension and job discontent. Educational psychology, 36(3), 569-594.

Kreber, C. (2010). Academics' teacher identities, authenticity and pedagogy. Studies in Higher Education, 35(2), 171-194.

Kuiga, J.J. (2018). Assessment of the effect of the head teacher's instructional supervision roles on pupil's academic performance in primary schools in Ifakara town council (Doctoral dissertation, The University of Dodoma).

Margutti, P. (2011). Teachers' reproaches and managing discipline in the classroom: When teachers tell students what they do 'wrong'. Linguistics and Education, 22(4), 310-329. 
McCabe, A., \& O'Connor, U. (2014). Student-centred learning: the role and responsibility of the lecturer. Teaching in Higher Education, 19(4), 350-359.

Moreno-Murcia, J. A., Sicilia, A., Cervelló, E., Huéscar, E., \& Dumitru, D. C. (2011). The relationship between goal orientations, motivational climate and self-reported discipline in physical education. Journal of sports science \& medicine, 10(1), 119.

Osher, D., Bear, G. G., Sprague, J. R., \& Doyle, W. (2010). How can we improve school discipline? Educational researcher, 39(1), 48-58.

Philipp, A., \& Kunter, M. (2013). How do teachers spend their time? A study on teachers' strategies of selection, optimisation, and compensation over their career cycle. Teaching and teacher education, 35, 1-12.

Raaper, R., (2019). Students as consumers? A counter perspective from student assessment as a disciplinary technology. Teaching in Higher Education, 24(1), pp.1-16.

Robinson, K. J., Mayer, S., Allen, A. B., Terry, M., Chilton, A., \& Leary, M. R. (2016). Resisting self-compassion: Why are some people opposed to being kind to themselves? Self and Identity, 15(5), 505-524.

Rotgans, J. I., \& Schmidt, H. G. (2011). The role of teachers in facilitating situational interest in an active-learning classroom. Teaching and teacher education, 27(1), 37-42.

Skaalvik, E. M., \& Skaalvik, S. (2011). Teacher job satisfaction and motivation to leave the teaching profession: Relations with school context, feeling of belonging, and emotional exhaustion. Teaching and teacher education, 27(6), 1029-1038.

Smits, I. A., Timmerman, M. E., \& Stegeman, A. (2016). Modelling non-normal data: The relationship between the skew-normal factor model and the quadratic factor model. British Journal of Mathematical and Statistical Psychology, 69(2), 105-121.

Tang, L. C., \& Than, S. E. (1999). Computing process capability indices for non-normal data: a review and comparative study. Quality and Reliability Engineering International, 15(5), 339-353.

Thomas, G. (2010). Facilitator, teacher, or leader? Managing conflicting roles in outdoor education. Journal of Experiential Education, 32(3), 239-254.

Torres, A. C. (2016). Teacher Efficacy and Disciplinary Expectations in Charter Schools: Understanding the Link to Teachers' Career Decisions. Journal of School Choice, 10(2), 171-199. doi:10.1080/15582159.2016.1152528

Ulug, M., Ozden, M. S., \& Eryilmaz, A. (2011). The effects of teachers' attitudes on students' personality and performance. Procedia-Social and Behavioral Sciences, 30, 738-742.

van Albada, S. J., \& Robinson, P. A. (2007). Transformation of arbitrary distributions to the normal distribution with application to EEG test-retest reliability. Journal of neuroscience methods, 161(2), 205-211. 